Original Paper

doi: $\underline{10.15826 / \text { recon.2018.4.3.014 }}$

\title{
The determinants of budget revenues of Russian regions
}

\author{
Marina Yu. Malkina \\ Lobachevsky State University of Nizhny Novgorod, Nizhny Novgorod, Russia; e-mail: mmuri@yandex.ru
}

\begin{abstract}
This paper discusses the determinants of regional budget revenues and evaluates their impact on the level of budget provision of Russian regions. We used the panel data on 80 Russian regions in 2006-2014 embracing average population, GRP disaggregated by main economic activities, tax revenues both collected and allocated at the regional level, intergovernmental aid and total budget revenues of consolidated budgets. We applied the least-squares methods with fixed and random effects to estimate the regressions between the structure of employment in main economic activities and the collected tax revenues in Russian regions. The constructed model allowed us to distinguish activities with positive and negative influence of employment on the general tax level and to determine the elasticity of the collected tax revenue per capita with respect to the shares of employees engaged in various economic activities. Further we applied the weighted least-squares method to estimate the model, demonstrating dependency of the budget revenue per capita in Russian regions on the collected tax revenue per capita, the level of tax absorption and the share of intergovernmental transfers in consolidated regional budgets. The constructed model demonstrated high elasticity of budget provision of Russian regions with respect to the general tax level, and even more with respect to the level of tax absorption. Nevertheless, the inter-budgetary transfers showed a very slight positive impact on the dispersion of the regional budget revenue per capita over the given period. Our findings are applicable to the management of budget revenues at the regional level and to the improvement of the Russian model of fiscal federalism.
\end{abstract}

\section{KEYWORDS}

region; budget revenue, determinants, economic activities, GRP per capita

\section{FOR CITATION}

Malkina, M. Yu. (2018)

The determinants of budget revenues of Russian regions. R-economy, 4(3), 95-104. doi: $10.15826 /$ recon.2018.4.3.014

\section{Детерминанты бюджетных доходов российских регионов}

\author{
М. Ю. Малкина \\ Нижегородский государственный университет, Нижний Новгород, Россия, е-таil: mmuri@yandex.ru
}

\section{PEЗЮМЕ}

В данной статье обсуждаются детерминанты доходов региональных бюджетов и оценивается их влияние на уровень бюджетной обеспеченности регионов Российской Федерации. Мы использовали данные по 80 регионам России за 2006-2014 годы, включающие среднее население, ВРП с разбивкой по основным видам экономической деятельности, налоговые поступления, как собранные, так и оставшиеся на уровне регионов, размер межправительственной помощи и общие доходы консолидированных бюджетов субъектов РФ. Мы применили метод наименьших квадратов с фиксированными и случайными эффектами для оценки регрессионных зависимостей между структурой занятости в основных видах экономической деятельности и собранными налоговыми поступлениями в российских регионах. Построенная модель позволила выявить, занятость в каких видах экономической деятельности оказала положительное, а в каких отрицательное влияние на общий уровень налоговых поступлений и определить эластичность собранных налогов на душу населения относительно долей занятых в различных видах экономической деятельности. Далее мы применили взвешенный метод наименьших квадратов для оценки модели, демонстрирующей зависимость доходов бюджетов на душу населения в российских регионах от собранных налоговых поступлений на душу населения, уровня абсорбции налогов и доли межбюджетных трансфертов в консолидированных бюджетах субъектов РФ. Построенная модель продемонстрировала высокую эластичность бюджетной обеспеченности регионов России к общему уровню налогообложения и еще большую эластичность - к уровню абсорбции налогов. В то же время межбюджетные трансферты оказали незначительное положительное влияние на снижение разброса среднедушевых доходов региональных бюджетов в рассматриваемом периоде. Наши выводы могут быть использованы для управления доходами бюджетов на региональном уровне и улучшения российской модели фискального федерализма.

\section{КЛЮЧЕВЫЕ СЛОВА}

регион; доходы бюджета; детерминанты; виды экономической деятельности; ВРП на душу населения

\section{ДЛЯ ЦИТИРОВАНИЯ}

Malkina, M. Yu. (2018)

The determinants of budget revenues of Russian regions. R-economy, 4(3), 95-104. doi: 10.15826/recon.2018.4.3.014 


\section{Introduction}

Russia occupies a vast territory spread over different climatic zones. A variety of natural conditions predetermine the diversity of economic structures of Russian regions and levels of their development. Moreover, the spatial location of regions, their proximity to the center and to economically advanced or, on the contrary, poor territories play a significant role in their development. The conditions of regional economies are also influenced by their previous paths of development, the functions that were attributed to these regions earlier in the centrally planned economy, the authority of regional leaders and their interrelationship with the federal center.

There were substantial disparities in the levels of development and budget provision of Russian regions during the entire period of market transition, although these disparities were steadily decreasing until recently. Indeed, in 2009, the gap in the GRP per capita between the most prosperous region, Nenets Autonomous District, and the most lagging region, the Republic of Ingushetia, amounted to 67.1 times, while the national average was 224.2 thousand rubles per capita. In addition, in 2009, the interregional population-weighted coefficient of variation of the GRP per capita was .84 . In 2014, the gap in the GRP per capita decreased noticeably - up to 39.5 times, while the coefficient of variation declined slightly and reached 0.81 . After 2014, the opposite tendency was observed: the gap in the GRP per capita grew up to 54.5 in 2016 while the coefficient of variation decreased slightly to the level of 0.786 . Despite these changes, both the top and the bottom regions in the ranking remained the same in 2016 as in 2009.

Regarding the budget provision of Russian regions, the situation was much better due to the active redistribution policy of the state. The interregional inequality in budget provision of Russian regions was considerably lower compared to the above-described regional disparities in the GRP per capita but still significant and growing in recent years. Thus, in 2011, the gap between the revenue per capita of the consolidated budget of the most prosperous region, Nenets Autonomous District, and the revenue of the most lagging region, the Republic of Dagestan, amounted to 12.1 times. The interregional population-weighted coefficient of variation of budget provision of Russian regions was . 55 in 2011. By 2015, the gap between Chukotka Autonomous District, ranked first by budget revenue per capita, and the Republic of Dagestan, which ranked last, had increased to 15.7 times, and the interregional coefficient of variation reached .61 .

In our study we assume that the sectoral structure of the country's economy plays a decisive role in budget provision of regional economies. It determines the level of the tax revenue that can potentially be collected there. Indeed, the largest level of tax return in the inter-crisis period of 2009-2013 was found in the mining industry, where the ratio of the collected tax revenue to the gross added value amounted to $53.7 \%$, followed by the manufacturing industry (21.3\%). The lowest level of the tax return rate was in agriculture (2.3\%). At the same time, the tax rules in Russia are set in such a way that the least evenly distributed taxes, namely the mineral extraction tax and the value added tax, are fully allocated at the federal budget level. Consequently, the tax revenues of more productive sectors, such as the extractive industry, are shared with the federal center in a larger proportion compared to tax revenues of other sectors. This partially mitigates the influence of the sectoral structure of economy on the budget provision of regions. In addition, the regional level of the tax return within economic activities varies significantly, which is mainly due to the differences in structures and conditions of these activities in regions, and, regarding the mining and quarrying industry, different quality of fields and different stages of their extraction.

The distribution of tax returns in Russian regions is influenced not only by the sectoral structure of regional economies, but also by differences in the application of tax exemptions and privileges. For instance, preferential tax regimes in special economic zones of some manufacturing regions significantly affects their level of tax returns. Moreover, the amount of collected taxes in regions depends on behavioral practices of the population and enterprises in these regions, the levels of tax discipline, tax compliance and tax evasion, and the quality of tax administration.

The distribution of intergovernmental transfers from the federal center to regions increases their financial resources and supports the alignment of regional budget provision. In addition to the equalization of budget revenues per capita, the system of intergovernmental aid in Russia is aimed at other purposes: balancing of regional budgets, funding of social mandates delegated to the sub-federal level from the higher authorities, and stimulation of investment activity in the regions. To achieve these goals, various types of budgetary 
assistance were elaborated, including subsidies, subventions, grants and other inter-budgetary transfers. Meanwhile, some of these objectives may be in conflict with others. Thus, stimulation may contradict equalization.

In this research, we examine the determinants of regional budget revenues per capita related both to the sectoral structure of regional economies and to the institutional features of the tax and budgetary systems in Russia.

\section{Literature Overview}

In research literature, different approaches are applied to studying regional budget revenues. First of all, there are papers that analyze the impact of macroeconomic factors (the exchange rate, oil prices, economic growth and inflation) on the total revenue of the budgetary system [1] or more specific factors such as tax revenues, interbudgetary transfers and so on. Some researchers have developed the ways to exclude the combined influence of macroeconomic factors on budget revenue [2]. Other authors examined the problems of sub-federal budgets in Russia in their relation to the current geopolitical situation, the impact of mutually imposed sanctions and the high dependence of Russian economy on the global energy market condition [3].

Castro and Camarillo [4] analyzed the impact of economic, structural, institutional and social factors on tax revenues in OECD countries in 2001-2011. They found that tax revenues as a percentage of GDP in these countries were positively related to GDP per capita, the industry value added as a percentage of GDP and civil liberties, whereas they were inversely dependent on the agriculture value added as a percentage of GDP and the share of foreign direct investment in gross fixed capital formation.

Other authors focused on institutional and behavioral factors affecting budget revenue and budget deficit of sub-federal entities in federal states. For example, Breuille and Vignot [5] modeled the impact of redistribution policy on financial behavior and fiscal discipline of the recipient regions. The authors concluded that such policy can encourage the regions to create overlapping schemes that could exacerbate the problem of a soft budget constraint. Huber and Runkel [6] developed another theoretical model simulating the relationship of the federal center and regions with different rates of time preference. The authors showed that the asymmetry of information can lead to ineffective redistribution of resources in favor of recipients. They proposed to establish differentiated institutions for two types of regions within the fiscal constitution: weak debt limits for contributors and strict debt limits for recipients. Such institutions should allow the federal center to overcome the information asymmetry through self-selection of regions.

In the context of our research, we should also mention the works on short- and long-term effects of redistribution of financial resources through the budgetary system. There are studies pointing out that the efficiency of inter-budgetary aid for development of a territory and the subsequent increase of its level of budgetary provision depends on how the received funds are spent. For instance, Kappeler, Solé-Ollé, Stephan and Välilä in their study [7] found that the use of intergovernmental transfers for production of public goods and investment in infrastructure of regional economies can stimulate economic growth.

It should be emphasized that a considerable part of inter-budgetary transfers in Russia is aimed at equalization of budgetary provision of regions, balancing sub-federal budgets according to the specific needs and the cost of living in regions, and financing the so-called social mandates, which are delegated from the federal center to the regional level. Based on the econometric models of various specifications, the researchers came to contradictory conclusions about the efficiency of inter-budgetary aid in Russian economy. For example, Yushkov [8] found that intergovernmental transfers positively affected economic growth in Russian regions in 2005-2012. At the same time, Isaev [9] demonstrated that inter-budgetary transfers from the federal centre to Russian regions had a negative impact on their economic growth in 2005-2014. Meanwhile, Martinez-Vasquez and Timofeev [10] found that intraregional budget transfers, distributed among municipalities for equalization of their budgetary provision, positively affected regional economic growth in 1999-2008.

However, centralized funding of large investment projects aimed at regional development has been a prevalent trend. Some researchers studied the consequences of allocation of financial resources within the framework of national projects. Belov [11] showed that investment from sub-federal budgets is more conducive to growth and development of Russian regions than investment from the federal budget. Therefore, the author came to the conclusion that the transfer of investment funds 
from the federal center to Russian regions should foster regional economic development.

Other researchers applied the deterministic factor analysis to study sub-federal budget revenues in the Russian Federation. A multiplicative model of the regional budget revenues was used to measure the changes in budgetary provision of Russian regions at consequent stages of budgetary process such as collection of tax revenues in regions, tax sharing with the federal center, attraction of non-tax revenues in regions, intergovernmental transfers and the regions' borrowing from other levels of the budgetary system and outside it [12]. In addition, the changing level of regional disparities in sub-federal budget provision was evaluated and the conclusion was drawn about the efficiency of various stages of the budgetary process in addressing interregional inequality. In yet another study [13], the author proposed an additive model of sub-federal budget revenues in Russia and carried out decomposition of the general inequality in the provision of regional budgets by various tax and non-tax sources.

Some authors analyzed the interrelationship between sectoral structures of regional economies and their budget revenues [14]. In particular, Paredesa and Rivera [15] found that in countries with a high share of mining, in GDP the mineral extraction tax can displace other taxes. The regression model constructed for Russian regions in [16] showed that more specialized economies had a higher level of tax return, while more diversified economies showed a higher degree of its stability.

In this study, we apply the panel data of Russian regions in 2006-2014 to econometric modeling of regional budget revenues. The purpose of this research is to select and substantiate exogenous factors that have a complementary impact on the level of the per capita revenue of the consolidated budgets of Russian regions. We also intend to show the connection between the budgetary provision of Russian regions, their economic structures, and the peculiarities of their participation in inter-fiscal interactions. We are also going to construct alternative econometric models and interpret their results.

\section{Data and Methods}

The study is based on the pooled spatial-temporal sample covering 747 observations on 83 Russian regions in 2006-2014. The initial data are provided by the Federal State Statistic Service and the Federal Tax Service of Russian Federation.
We tested a set of the following independent variables presumably influencing the budget revenue per capita in Russian regions:

1. Variables related to the sectoral structure of regional economies:

- the gross value added in main economic activities per capita;

- the labor productivity in main economic activities calculated as the ratio of the gross value added to employment in these activities;

- the share of economic activities in the total gross value added;

- the share of economic activities in total employment;

2. Variables related to the state of the tax and budgetary systems and interbudgetary relationships:

- the general level of taxation (determined as the ratio of the collected tax revenues to GRP and to constant population of regions);

- the level of tax absorption - the share of tax revenues remaining in the consolidated regional budgets after the distribution of the total tax revenues collected in the regions between the levels of the budgetary system;

- the share of remittances transferred to regional budgets from the federal center in the total revenue of regional budgets.

To bring the nominal values of these variables in various years to a single scale of prices, we calculated their real values. For this purpose, we used the cumulative GDP deflator indices determined on the accrual basis. Since we constructed the regressions of the logarithmic type, individual observations with negative and zero values were omitted.

The selection of independent variables for regression was carried out on the basis of the correlation matrix, taking into account both the relationship of these variables with the dependent variable and the absence of multicollinearity. We tested models of different specifications, including the models with fixed and random effects to which the least squares method was applied. The significance of the models was estimated on the basis of the Fisher criterion, and significance of its coefficients - on the basis of the Students tests. We also checked the models for the presence of heteroscedasticity using the White test.

\section{Results and Discussion}

Figure 1 shows a wide dispersion of the budgetary provision of Russian regions in real terms on average in 2006-2014. 


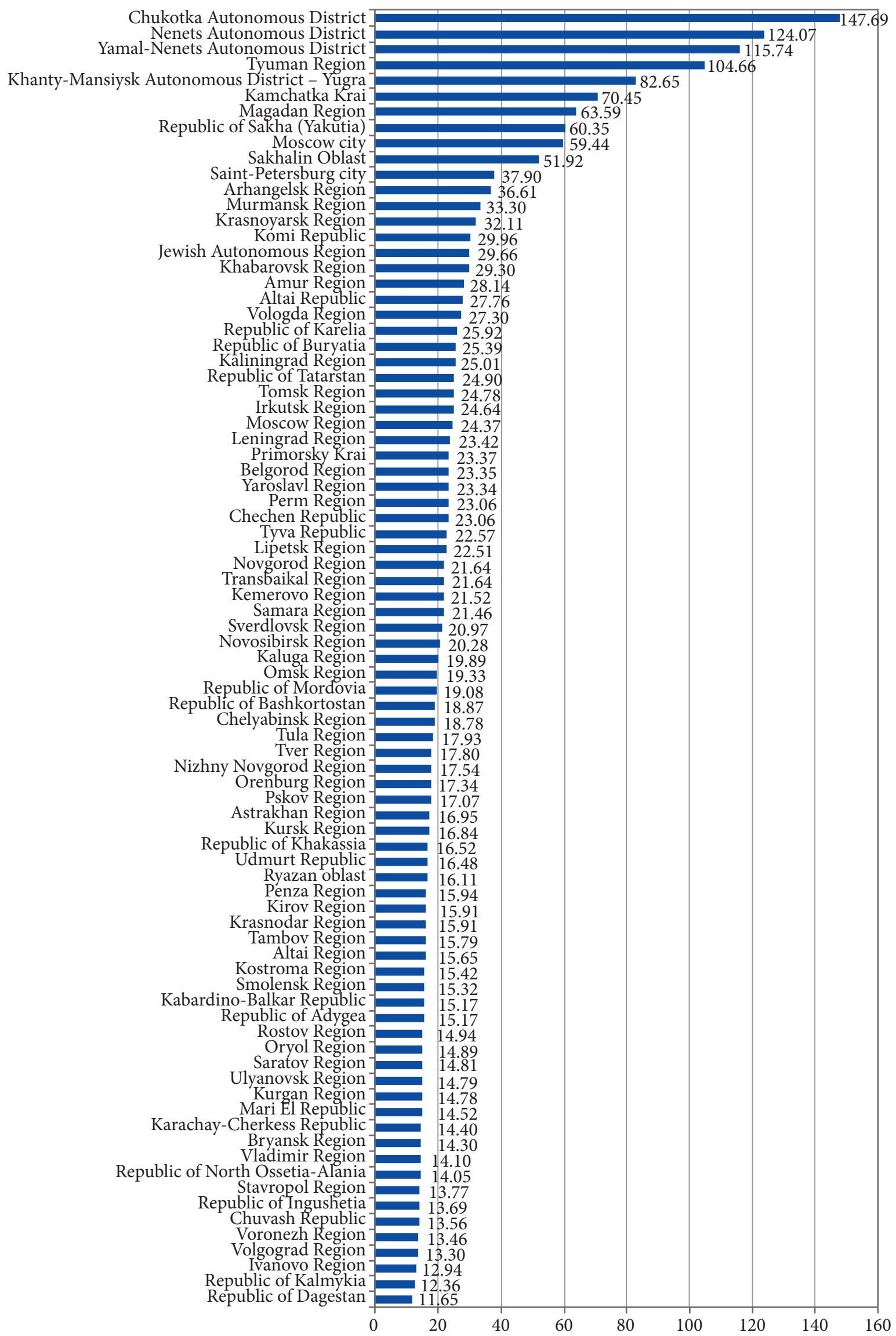

Russian regions' annual average budget revenue per capita in 2006-2014 in constant prices of 2005, thousand deflated rubles 
According to the results obtained, the budget revenue per capita in the richest region (Chukotka Autonomous District) was 12.7 times higher than that of the poorest region (Dagestan). Only in 17 out of 83 regions the level of budget provision exceeded the country average. The ratio of the median value to the mean value of budgetary provision was $70.6 \%$, which indicated a left bias in the distribution of this variable. It should be noted that the deflation of indicators in time series reduced the level of interregional inequality of budget provision. However, we did not take into account the initial distribution of prices and differences in the cost of living in the base period of study, which could decrease the measured inequality to a greater extent.

Among the leaders by the level of budgetary provision, we can primarily find the regions specialized in extractive industry and characterized by the relatively low population density (namely, Nenets Autonomous District, which is a part of Arkhangelsk region; Khanty-Mansiysk and Yamalo-Nenets Autonomous Districts, which are parts of Tyumen region; Chukotka Autonomous District, Kamchatka Krai, the Republic of Sakha, Magadan and Sakhalin regions, all situated in the Far Eastern Federal District). A high position by the level of budget revenue is also occupied by the capital city of Moscow, where a large number of state agencies and financial institutions are located.
Among the laggards, we see the regions deprived of any comparative advantages of both natural and artificial origin, such as the Republic of Kalmykia, Ivanovo region and the Chuvash Republic. Moreover, almost all North Caucasian republics (except for the Chechen Republic) are lagging behind as well as Stavropol region.

This situation in Russian regions is the result of many processes. The budgetary provision is affected by the volume of the collected tax revenue, which is shared with the federal budget, non-tax revenues (income from public and municipal property and sale of tangible and intangible assets etc.) and availability of inter-budgetary aid. Meanwhile, the initial level of budgetary provision in each region is predetermined by the tax revenue collected on its territory, the amount of which depends to a large extent on the sectoral structure of regional economy.

Table 1 compares the following three sectoral structures of regional economies: the distribution of employed persons, production of GRP and collected taxes in main economic activities. It indicates the outstanding role of the mining sector in tax revenues. In this sector, both the labor productivity and the tax return level were 3.7 times higher than the national average. As a result, the tax revenue per employee in mining and quarrying exceeded the average level in all sectors by almost 14 times. At the same time, an increased

Structural parameters of tax revenues in Russian regions in 2006-2014, \%

\begin{tabular}{|c|c|c|c|c|c|c|c|c|c|}
\hline \multirow[t]{2}{*}{ Economic Activities } & \multicolumn{3}{|c|}{$\begin{array}{l}\text { Share in total } \\
\text { employment }\end{array}$} & \multicolumn{3}{|c|}{ Share in total GRP } & \multicolumn{3}{|c|}{$\begin{array}{c}\text { Share in collected tax } \\
\text { revenue }\end{array}$} \\
\hline & MV & SD & $\mathrm{CV}$ & MV & SD & $\mathrm{CV}$ & MV & SD & $\mathrm{CV}$ \\
\hline Agriculture, hunting and forestry (A) & 11.4 & 5.9 & 0.52 & 9.3 & 6.3 & .68 & .6 & 2.0 & 3.29 \\
\hline Fishing, fish farming (B) & .4 & 1.2 & 2.83 & 1.1 & 6.7 & 6.11 & .1 & 2.3 & 16.26 \\
\hline Mining and Quarrying (C) & 2.3 & 4.3 & 1.86 & 8.7 & 15.1 & 1.73 & 32.5 & 23.0 & .71 \\
\hline Manufacturing (D) & 14.5 & 6.3 & .44 & 18.4 & 11.3 & .62 & 18.1 & 19.9 & 1.10 \\
\hline Electricity, gas and water $(\mathrm{E})$ & 3.4 & 1.5 & .44 & 4.5 & 2.7 & .61 & 2.8 & 4.3 & 1.53 \\
\hline Construction $(\mathrm{F})$ & 7.5 & 2.5 & .33 & 7.9 & 4.1 & .52 & 4.9 & 4.6 & .94 \\
\hline Wholesale and retail trade; repair $(\mathrm{G})$ & 15.9 & 3.6 & .23 & 16.7 & 7.0 & .42 & 11.5 & 13.6 & 1.19 \\
\hline Accommodation and food service activities $(\mathrm{H})$ & 1.7 & .5 & .30 & 0.9 & .5 & .52 & 0.6 & .5 & .82 \\
\hline Transport and telecommunications (I) & 8.0 & 1.9 & .24 & 11.7 & 4.9 & .42 & 8.1 & 7.1 & .88 \\
\hline Real estate, leasing and services (J) & 1.3 & .5 & .41 & 0.2 & .5 & 2.22 & 5.2 & 4.6 & .88 \\
\hline Financial activities $(\mathrm{K})$ & 6.3 & 2.4 & .38 & 7.4 & 3.1 & .43 & 9.9 & 4.8 & .48 \\
\hline Public administration and defense & 6.8 & 2.3 & .33 & 4.8 & 3.0 & .63 & 1.7 & 5.6 & 3.19 \\
\hline Education & 9.5 & 2.3 & .24 & 3.4 & 1.8 & .52 & 1.4 & 2.0 & 1.40 \\
\hline Health and social services & 7.3 & 1.3 & .18 & 3.8 & 1.8 & .46 & 1.1 & 1.9 & 1.65 \\
\hline Public utilities & 3.7 & .7 & .19 & 1.2 & .5 & .43 & 1.3 & .9 & .66 \\
\hline
\end{tabular}

Note: $M V$ - interregional mean value, $S D$ - interregional standard deviation, $C V$ - interregional coefficient of variation, which is the ratio of $S D$ to $M V$. 
level of labor productivity in certain spheres (fishing, fish farming; transport and telecommunications; manufacturing; electricity, gas and water; finance) and a higher level of tax return in some other spheres (real estate, leasing and services; finance) ensured greater profitability of the tax system. Thus, the contribution of economic activities to overall tax revenues in regions and in the country as a whole depended on their share in employment and production.

Due to the fact that economic structures in the regions differ, their tax revenue levels also differ, which is evident from the corresponding standard deviations and coefficients of variation in activities. Thus, according to the distribution of employment, the regions are the most diverse in mining and quarrying, fishing and fish farming. By the share in GRP, they differ more in the aforementioned two activities, as well as in real estate, leasing and services. Finally, the share of regions in tax revenues varies most in fishing, fish farming, as well as in agriculture, hunting and forestry.

Our selection of structural variables that presumably shape the tax revenue per capita in regions was based on the criteria specified in the methodological part of the work. We proposed a model of the following specification:

$$
\ln \left(T R p c_{i t}\right)=\beta_{0}+\sum_{i=1}^{n} \beta_{i} \ln \left(X e m p_{i t}\right)+\varepsilon_{i t},
$$

where $T R p c_{i t}$ is the tax revenue per capita and $X e$ $m p_{i t}$ is the share of the corresponding activity in the total employment of the ith region in the period $t$. The model was estimated by means of three alternative methods presented in Table 2.

The constructed models are significant according to the Fisher criterion; the significance of their parameters (except for the intercept term) is confirmed by the Students test. In addition, they do not have multicollinearity and the residuals of the models are normally distributed.

According to the results obtained, those regions whose population is employed mainly in the sectors of mining and quarrying; electricity, gas and water production; construction; transport and telecommunications; real estate, leasing and services and finance had a higher level of collected tax revenues per capita on average. At the same time, those regions whose employment concentrated mainly in agriculture, hunting and forestry; manufacturing; wholesale and retail trade, repair;

Table 2

Models: dependent variable $\ln \left(T R p c_{i t}\right)$

\begin{tabular}{|c|c|c|c|}
\hline \multirow[t]{2}{*}{ Variable } & \multicolumn{3}{|c|}{ Coefficient of regression (Standard error), significance } \\
\hline & $\begin{array}{c}\text { Model 1: } \\
\text { Pooled OLS regression }\end{array}$ & $\begin{array}{c}\text { Model 2: } \\
\text { OLS with fixed effects }\end{array}$ & $\begin{array}{c}\text { Model 3: } \\
\text { GLS with random effects }\end{array}$ \\
\hline const & $-1.154(.836)$ & $.129(.789)$ & $-.591(.795)$ \\
\hline Ln(A_emp) & $-.250(.029) * * *$ & $-.242(.031)^{\star * \star}$ & $-.245(.029)^{\star * \star}$ \\
\hline Ln(C_emp) & $.073(.014)^{* * *}$ & $.058(.015)^{\star * *}$ & $.068(.014)^{\star * *}$ \\
\hline Ln(D_emp) & $-.097(.042)^{* *}$ & $-.122(.044)^{\star * *}$ & $-.106(.042)^{\star * *}$ \\
\hline Ln(E_emp) & $.300(.077)^{* * *}$ & $.306(.076)^{* * *}$ & $.354(.073)^{\star * *}$ \\
\hline Ln(F_emp) & $.269(.079) * * *$ & $.325(.082)^{* * *}$ & $.279(.079)^{\star * *}$ \\
\hline Ln(G_emp) & $-1.287(.088)^{\star * \star}$ & $-1.207(.089)^{\star * \star}$ & $-1.290(.088)^{* * *}$ \\
\hline Ln(H_emp) & $-.125(.059)^{\star *}$ & - & - \\
\hline Ln(I_emp) & $.653(.097)^{\star * *}$ & $.605(.098)^{\star \star \star *}$ & $.602(.094)^{* * *}$ \\
\hline Ln(J_emp) & $.188(.071)^{\star * *}$ & $.275(.075)^{\star * \star}$ & $.211(.070)^{\star * *}$ \\
\hline Ln(K_emp) & $.627(.085)^{\star * *}$ & $.669(.091)^{\star * *}$ & $.626(.085)^{* * *}$ \\
\hline Ln(L_emp) & $-.878(.088)^{\star * *}$ & $-.811(.095)^{\star * *}$ & $-.894(.088)^{\star * *}$ \\
\hline Ln(M_emp) & $-.470(.135)^{\star * *}$ & - & $-.425(.134)^{\star * *}$ \\
\hline Ln(N_emp) & $-.531(.170)^{\star \star \star}$ & $-.689(.156)^{\star * *}$ & $-.510(.170)^{\star \star \star}$ \\
\hline Ln(O_emp) & $-.540(.104)^{\star * \star}$ & $-.761(.109)^{\star * \star}$ & $-.609(.099)^{\star \star \star}$ \\
\hline Adjusted R-squared & .822 & .821 & - \\
\hline Durbin-Watson statistic & 1.810 & 1.962 & - \\
\hline Number of observations & 693 & 693 & 693 \\
\hline
\end{tabular}


accommodation and food service activities; public administration and defense; education; health and social services and public utilities have a lower level of the collected tax revenues per capita on average. The coefficients of regressions show the elasticity of tax revenues with respect to the share of employment in the corresponding activity.

The second step of our research was modeling the interrelationship between budget revenues per capita as a dependent variable and the general level of taxation, the level of tax absorption and the share of transfers in regional budget revenues as independent variables. Table 3 shows the descriptive statistics of the explained and explanatory variables.

Table 3

Descriptive statistics of the parameters related to the consolidated budgets

of the Russian regions in 2006-2014, \%

\begin{tabular}{|l|c|r|r|r|}
\hline \multicolumn{1}{|c|}{ Variable } & Note & MV & \multicolumn{1}{c|}{ SD } & CV \\
\hline $\begin{array}{l}\text { Budget revenue per capita, } \\
\text { thousand deflated rubles }\end{array}$ & $B R p c_{i t}$ & 28.11 & 36.99 & 1.32 \\
\hline $\begin{array}{l}\text { General level of taxation, } \\
\text { thousand deflated rubles }\end{array}$ & TRpc & 34.16 & 79.72 & 2.33 \\
\hline Level of tax absorption & Selt & .74 & .20 & .26 \\
\hline $\begin{array}{l}\text { Share of transfers in total } \\
\text { budget revenues }\end{array}$ & Transf & .34 & .19 & .54 \\
\hline
\end{tabular}

Note: $M V$ is the mean value; $S D$, the standard deviation; and $C V$ is the coefficient of variation.

The general tax level turned out to be a statistically significant parameter that positively affected the average budget revenues, which was completely correspondent with the logic of economic processes. The linear coefficient of the correlation between the tax revenue per capita and the budget revenue per capita in Russian regions in the given period equaled .57. However, the strong heteroscedasticity in this dependency was observed even visually.

The relationship between the level of tax absorption in regions and the total budget revenues per capita appeared to be slightly negative. Indeed, the Pearson correlation of these variables was only -.13 . At the same time, we found a significant negative relationship between the collected tax revenues per capita and the share of taxes left in regional budgets after their distribution among the levels of budgetary system. The dependency between the general tax level and the level of tax absorption was described by the power function of the following specification:

$$
\text { Self }_{i t}=7.6 T R p c_{i t}^{-2.036}, R^{2}=0.47 \text {. }
$$

As for transfers, we did not obtain any strong evidence showing their connection to the level of budget provision, albeit the inverse dependency was expected. We identified several reasons for this phenomenon. First of all, significant and diverse inter-budgetary transfers received from the federal budget by some lagging regions, for example, the republics of Chechnya, Tyva, Altai, in fact, raised their level of budgetary provision even higher than the national average. Secondly, when determining the needs of regions in intergovernmental transfers, fiscal authorities take into account not only the available regional budget revenues, but also the necessary expenses, which depend on the cost of living and on the specific needs of each particular region. Hence, some seemingly more affluent regions of the Far Eastern Federal District, such as Chukotka Autonomous District, Magadan region and Kamchatka, receive significant transfers from the center, which further increases their level of budget provision.

Despite the ambiguity of some dependencies, we proposed a regression of the following specification:

$$
\begin{aligned}
\ln \left(B R p c_{i t}\right)= & \beta_{0}+\beta_{1} \ln \left(\text { TRpc }_{i t}\right)+\beta_{2} \ln \left(\text { Self }_{i t}\right)+ \\
& +\beta_{3} \ln \left(\text { Transf }_{i t}\right)+\varepsilon_{i t} .
\end{aligned}
$$

To cope with the heteroscedasticity and abnormality of the distribution of residues, we estimated this model using the weighted least-squares method, which means that the natural logarithm of GDP per capita was treated as a weight parameter. Moreover, in the estimation of the regression we used robust standard errors. The resulting model is presented in Table 4.

Table 4

Model: dependent variable $\ln \left(B R p c_{i t}\right)$

\begin{tabular}{|l|r|}
\hline \multicolumn{1}{|c|}{ Variable } & Pooled WLS regression \\
\hline const & $1.652(.063)^{* * *}$ \\
\hline $\ln \left(\right.$ TRp $\left._{i t}\right)$ & $.649(.029)^{* * *}$ \\
\hline $\ln \left(\right.$ Selt $\left._{i t}\right)$ & $.809(.074)^{* * *}$ \\
\hline $\ln \left(\right.$ Trans $\left._{i t}\right)$ & $.063(.017)^{* * *}$ \\
\hline Adjusted $R$-squared & .705 \\
\hline Number of observations & 747 \\
\hline
\end{tabular}

Note: ${ }^{\star * \star}$ means that the coefficient is significant with $p<.01$; ${ }^{* *}$, the coefficient is significant with $p<.05$; ${ }^{*}$ the coefficient is significant with $p<0.1$.

In this regression, all exogenous variables are statistically significant and the directions of relationship between the exogenous and endogenous variables are completely consistent with the logic of economic processes. Indeed, the higher the lev- 
el of taxation, the level of tax absorption and the aid received from the federal center, the higher is the level of budget provision of Russian regions. Despite the concerns about possible multicollinearity, the VIF test did not confirm its existence in this model.

The estimated coefficients of the model can be interpreted as indicators of elasticity of the tax revenue with respect to the examined factors. For example, an increase in the tax revenue per capita collected in Russian regions by $1 \%$ leads to an increase in the budget revenue of the regions by $.65 \%$ on average. The elasticity of budget provision with respect to the level of tax absorption has proven to be even higher compared to the level of tax collection. Eventually, inter-budgetary transfers demonstrated the weakest impact on the changes in the budget revenue per capita in regions over time. It evidenced the diminishing role of intergovernmental aid in equalization of Russian regions' budget provision.

\section{Conclusion}

In this study, we analyzed the factors that influenced the revenues of consolidated regional budgets by using the panel data of Russian regions in 2006-2014. In the theoretical part of our paper, we studied the influence of the sectoral structure of economy, macroeconomic conditions, institutional features of the tax and budgetary systems, and public behavior on the level of average budget revenues of states and their constituent entities. In the empirical part of the paper, we selected the most relevant variables and constructed the models related to the two stages of budget revenue formation. In the first step, using ordinary least-squares methods with fixed and random effects, we built the dependency of the tax revenue per capita in real terms on the shares of economic activities in total employment in Russian regions. It allowed us to reveal the positive impact of employment in certain sectors (e.g. mining and real estate activities) and the negative impact of employment in other sectors (e.g. agriculture, trade and social sphere) on the general tax level in Russian regions. In the second step, by means of the weighted least-squares method, we constructed a regression model of the logarithm type, which demonstrated a positive impact of the general tax level, the level of tax absorption and the share of inter-budgetary transfers in consolidated budgets of Russian regions on their budget revenue per capita. We demonstrated the greatest influence of the level of tax absorption and the smallest effect of transfers on the reduction of regional disparities regions by budget provision.

The results obtained are basically consistent with some of our previous findings [12;13] and develop approaches to modeling regional differences on the level of budgetary provision. For further research, it is necessary to improve the methods of construction of regression models based on spatial-temporal data and to provide a more precise specification of the basic model by including proxy variables for institutional parameters of budgetary and tax systems as well as general public behavior.

\section{References}

1. Balaev, A., Gurvich, E., Prilepskiy, I., Suslina, A. (2014). Effect of Oil Price and Exchange Rate on the Fiscal Revenues. Financial Journal, 1(19), 5-16. (In Russ.)

2. Balaev, A. (2017). Factor Analysis of the Russian Budget System Revenues. Economic Polycy, 12(3), 8-37. (In Russ.) doi: 10.18288/1994-5124-2017-3-01

3. Povarova, A. I. (2017). Alarming Prospects of Russian Regional Budgets. Territorial Development Issues, 2(37), 1-10. Retrieved from http://vtr.isert-ran.ru/article/2200? lang=en (In Russ.)

4. Castro, G. Á., \& Camarillo, D. B. R. (2014). Determinants of Tax Revenue in OECD Countries over the Period 2001-2011. Contaduría y Administración, 59(3), 35-59. doi: 10.1016/S01861042(14)71265-3

5. Breuillé, M.-L., Vigneault, M. (2010). Overlapping Soft Budget Constraints. Journal of Urban Economics, 67(3), 259-269.

6. Huber, B., Runkel, M. (2008). Interregional Redistribution and Budget Institutions under Asymmetric Information. Journal of Public Economics, 92(12), 2350- 2361. doi: 10.1016/j.jpubeco.2008.01.008

7. Kappeler, A., Solé-ollé, A., Stephan, A., Välilä, T. (2013). Does Fiscal Decentralization Foster Regional Investment in Productive Infrastructure? European Journal of Political Economy, 31, 15-25. doi: $\underline{10.1016 / \text { j.ejpoleco.2013.03.003 }}$ 
8. Yushkov, A. (2015). Fiscal Decentralization and Regional Economic Growth: Theory, Empirics, and the Russian Experience. Russian Journal of Economics, 1(4), 404-418. doi: 10.1016/j. ruje.2016.02.004

9. Isaev A. G. (2016). Distribution of Financial Resources within the Budget System of the Russian Federation and Regional Economic Growth. Prostranstvennaya Ekonomika = Spatial Economics, 4, 61-74 (In Russ.). doi: 10.14530/se.2016.4.061-074

10. Martinez-Vazquez, J., Timofeev, A. (2014). Intra-Regional Equalization and Growth in Russia. Comparative Economic Studies, 56(3), 469-489. doi: 10.1057/ces.2014.7

11. Belov, A. (2018). Tax Revenues, Public Investments and Economic Growth Rates: Evidence from Russia. Journal of Tax Reform, 4(1), 45-56. doi: 10.15826/jtr.2018.4.1.044

12. Malkina, M. (2016). Evaluation of the Factors of Russian Regions' Convergence / Divergence in the Level of Budget Provision Based on the Decomposition of the Theil - Bernoulli Index. Prostranstvennaya Ekonomika = Spatial Economics, 3, 16-37 (In Russ.) doi: 10.14530/se.2016.3.016-037

13. Malkina, M. (2017). Decomposition of Spatial Inequality in Budget Provision by Income Sources: Case of Modern Russia. In: Nešleha, J., Plíhal, T., \& Urbanovský, K. (Eds). European Financial Systems 2017. Proceedings of the $14^{\text {th }}$ International Scientific Conference, Part 2. Brno: Masaryk University, 35-43. Retrieved from https://is.muni.cz/do/econ/sborniky/70896034/EFS2017-Proceedings 2 final.pdf

14. Liu, J., Hu, X., Wu, J. (2017). Fiscal Decentralization, Financial Efficiency and Upgrading the Industrial Structure: An Empirical Analysis of a Spatial Heterogeneity Model. Journal of Applied Statistics, 44(1), 181-196. doi: 10.1080/02664763.2016.1252733

15. Paredes, D., Rivera, N. M. (2017). Mineral Taxes and the Local Public Goods Provision in Mining Communities. Resources Policy, 53, 328-339. doi: 10.1016/j.resourpol.2017.07.007

16. Malkina, M. (2017). Influence of the Industrial Structure of Economy on the Risk Level of Russian Regions' Tax Systems. Acta Universitatis Agriculturae et Silviculturae Mendelianae Brunensis, 65(6), 2025-2035. doi: 10.11118/actaun201765062025

\section{Information about the author}

Marina Yu. Malkina - Professor of Economics, Lobachevsky State University of Nizhny Novgorod (23 Gagarin Avenue, 603950 Nizhnij Novgorod, Russia); e-mail: mmuri@yandex.ru. 